\title{
MBR-Assisted VFAs Production from Excess Sewage Sludge and Food Waste Slurry for Sustainable Wastewater Treatment
}

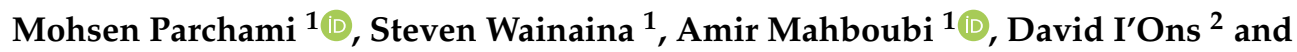 \\ Mohammad J. Taherzadeh ${ }^{1, * \mathbb{D}}$ \\ 1 Swedish Centre for Resource Recovery, University of Borås, SE 50190 Borås, Sweden; \\ mohsen.parchami@hb.se (M.P.); steven.wainaina@hb.se (S.W.); amir.mahboubi_soufiani@hb.se (A.M.) \\ 2 Gryaab AB, Norra Fågelrovägen, SE 41834 Gothenburg, Sweden; david.ions@gryaab.se \\ * Correspondence: mohammad.taherzadeh@hb.se; Tel.: +46-33-435-59-08; Fax: +46-33-435-40-03
}

Received: 19 March 2020; Accepted: 18 April 2020; Published: 23 April 2020

\begin{abstract}
The significant amount of excess sewage sludge (ESS) generated on a daily basis by wastewater treatment plants (WWTPs) is mainly subjected to biogas production, as for other organic waste streams such as food waste slurry (FWS). However, these organic wastes can be further valorized by production of volatile fatty acids (VFAs) that have various applications such as the application as an external carbon source for the denitrification stage at a WWTP. In this study, an immersed membrane bioreactor set-up was proposed for the stable production and in situ recovery of clarified VFAs from ESS and FWS. The VFAs yields from ESS and FWS reached 0.38 and $0.34 \mathrm{gVFA} / \mathrm{gVS}_{\text {added }}$, respectively, during a three-month operation period without $\mathrm{pH}$ control. The average flux during the stable VFAs production phase with the ESS was $5.53 \mathrm{~L} / \mathrm{m}^{2} / \mathrm{h}$ while $16.18 \mathrm{~L} / \mathrm{m}^{2} / \mathrm{h}$ was attained with FWS. Moreover, minimal flux deterioration was observed even during operation at maximum suspended solids concentration of $32 \mathrm{~g} / \mathrm{L}$, implying that the membrane bioreactors could potentially guarantee the required volumetric productivities. In addition, the techno-economic assessment of retrofitting the membrane-assisted VFAs production process in an actual WWTP estimated savings of up to $140 € / \mathrm{h}$ for replacing $300 \mathrm{~kg} / \mathrm{h}$ of methanol with VFAs.
\end{abstract}

Keywords: wastewater; denitrification; carbon source; volatile fatty acids; immersed membrane bioreactor

\section{Introduction}

One of the consequences of the ever-growing global population is the generation of enormous amounts of different wastes on a daily basis. In order to build modern societies that maintain the balance between social, economic, and environmental sustainability, these waste streams should be effectively and efficiently treated. Among different waste streams, handling wastewater is of critical importance as its poor treatment and discharge to water bodies imposes a substantial environmental and ecological imbalance on marine life, in addition to diverse direct and indirect effects on human health [1,2]. In conventional wastewater treatment (WWT) systems, in order to remove carbonaceous compounds and nutrients such as nitrogen and phosphorous to obtain clean water accepted for discharge, the received influent wastewater undergoes different treatment stages of biochemical oxygen demand (BOD) reduction, nitrification, and denitrification (with different orders in different treatment plants) [3]. Figure 1 presents a general schematic of the main wastewater treatment stages. 


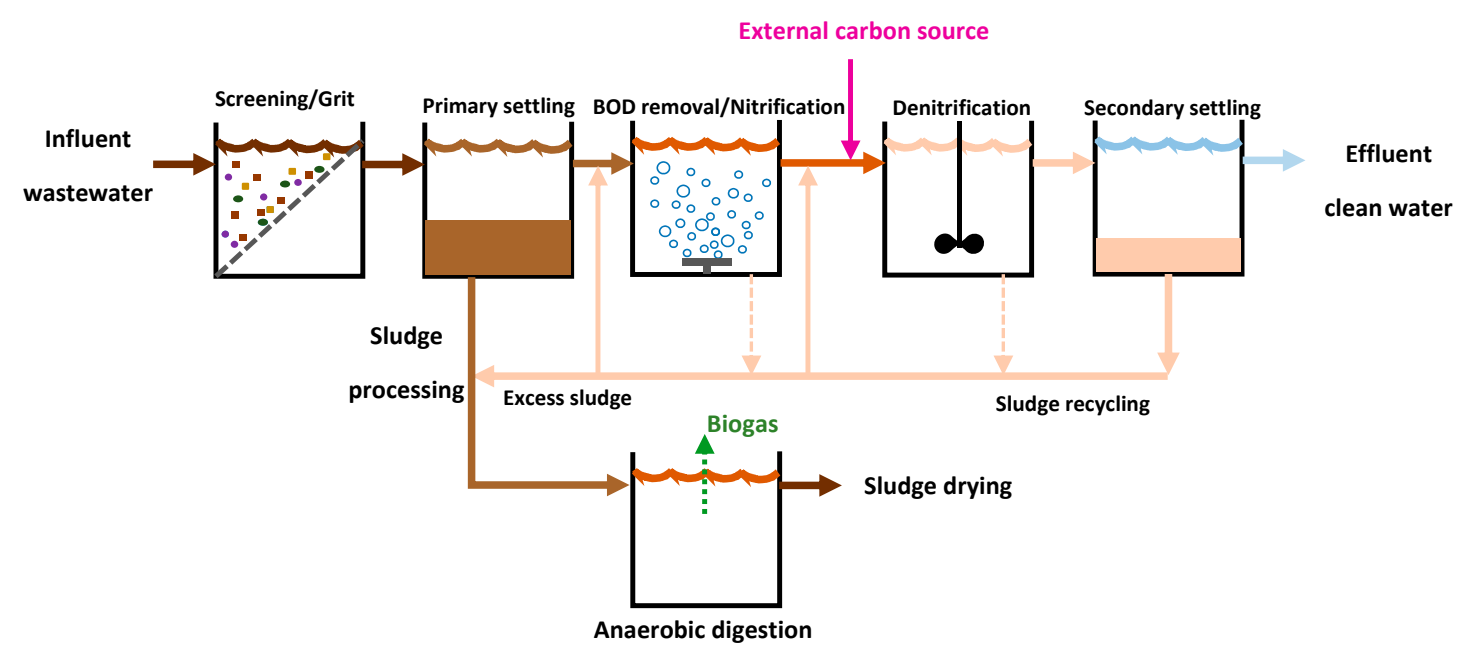

Figure 1. General processing stages at a conventional wastewater treatment plant aimed at biogas production from excess sewage sludge.

Conventionally, the excess sludge discharged at different stages of treatment is directed to biogas and fertilizer production through anaerobic digestion (AD). For instance, in Sweden, about 204,000 tons of dry matter of sewage sludge (20.74 kg per capita) was produced in 2017, of which only $34 \%$ was used for agricultural purposes [4]. In addition to the excess sewage sludge, food waste is one of the most studied wastes streams that is mainly treated using anaerobic digestion due to its richness in organic strength $[5,6]$. The biochemical reactions in the AD process take place in four interdependent stages namely: hydrolysis, acidogenesis, acetogenesis, and methanogenesis (Figure 2) [7]. Biomethane is produced in the last stage of the AD process, while other metabolites such as volatile fatty acids (VFAs) and hydrogen are formed in the intermediate stages [8]. Biogas suffers low commercial value; however, a promising but hitherto not well-developed line of research is to extract and transform the intermediate products of AD (VFAs and $\mathrm{H}_{2}$ ). These compounds can be further converted into several high-value products, such as bioplastics, butanol and biodiesel [9]. The VFAs, such as acetic, butyric, and propionic acids, produced through $\mathrm{AD}$, can be used directly or indirectly as chemical building blocks in, for instance, textile and plastic production industries [8]. Along with VFAs, hydrogen is produced during acidogenesis, which has attracted great attention as a clean energy source. However, issues such as VFA loss due to conversion to methane, change in $\mathrm{pH}$, and cell inhibition by a high concentration of VFAs hinder obtaining high VFAs yields. In a mixed microbial culture, if the methanogens are not inhibited or the products of acidogenesis are not recovered efficiently, the VFAs will be lost through methanogenesis for methane production. Therefore, it is of great importance to be able to control the AD process to produce mainly desirable VFAs of higher value and application. However, a solution with a mixture of VFAs has a low market value, therefore, it needs to either be converted to other bioproducts or to be separated into pure components. Due to the formation of an azeotropic mixture with water, VFAs separation and recovery is laborious and energy intensive [10]. Thus, the direct application of VFAs mixture can eliminate extra energy intensive recovery processes and enhance economic feasibility. 


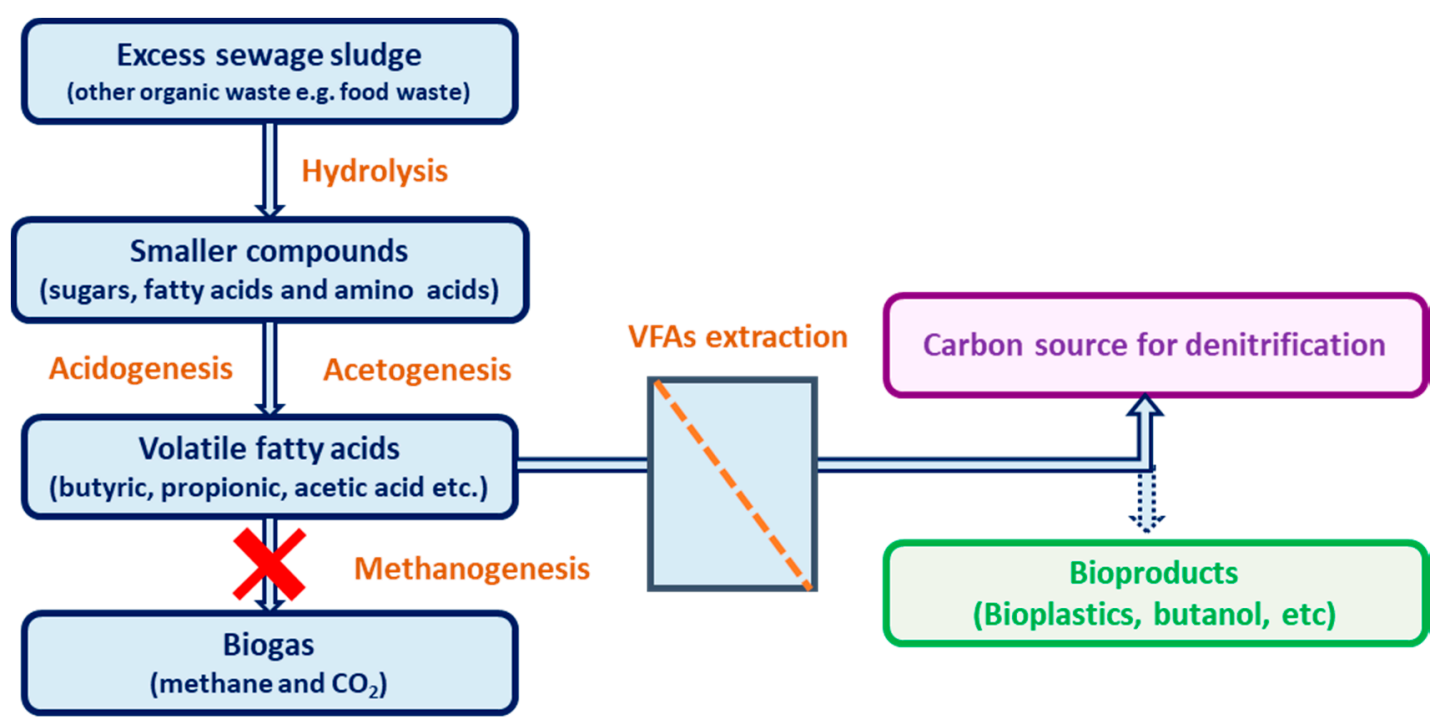

Figure 2. Anaerobic digestion of excess sludge and other organic wastes for the production of volatile fatty acids (VFAs) instead of biogas.

During the wastewater treatment process, unlike nitrification bacteria that use inorganic carbon sources such as $\mathrm{CO}_{2}$ to thrive on, the bacteria responsible for denitrification require organic carbon source for maintaining growth and acquiring energy [11]. The problem confronted here is that, as most of the organic carbon source has been depleted in the initial BOD removal stage, external organic carbon sources should be provided to the process. The external organic carbon sources, such as methanol, ethanol, and glucose, impose external loads on a wastewater treatment plant, resulting in it being a far from self-sustained independent process [12]. Other drawbacks associated with external carbon source provision include the extra purchase and transfer costs, occasional and seasonal changes in the price and availability, and the environmental unsustainability of the wastewater treatment process in the case of the application of fossil-fuel-derived carbon sources such as methanol. Moreover, safety and storage regulations should be imposed if hazardous and flammable sources such as methanol and ethanol are to be used [13]. Thus, a sustainable alternative for the external carbon source is needed in order to change the wastewater treatment process into a self-sustained process. VFAs could be alternative carbon sources for the denitrification process and, based on their production from waste streams, they can relieve the dependency on fossil-based carbon sources. Moreover, the mixture of VFAs can be used directly as a carbon source for the denitrification process without downstream purification demands. Many studies have tested the effectiveness of VFAs as a carbon source for the denitrification process [13-18]. In this regard, VFAs higher denitrification rates have been reported compared to methanol. Moreover, due to their continuous on-site production, extra costs such as transportation will be eliminated.

Although there has been extensive work on the production of VFAs from waste streams [19], the process cannot easily be scaled up to industrial level due to challenges faced during the recovery of VFAs from the system [10]. The recovery of VFAs from the bioreactor is crucial to the downstream processing, and production stability and efficiency [20]. Due to the complex physiochemical nature of the fermentation broth and low concentration of acids in the system, separating the VFAs from the fermentation broth is a challenging task [21]. Different separation techniques have been used for the recovery of the VFAs, such as distillation [22], liquid-liquid extraction [23], centrifugation [24], electrodialysis [25], and membrane filtration [9,21]. The membrane-assisted process seems to be a cost-effective and stable recovery method among the current separation methods, with low energy demands and a small footprint. Another study in our group [9] has reported an effective membrane-assisted process for production and in situ recovery of VFAs from synthetic food waste, resulting in high VFAs yield and productivity. 
Membrane-assisted cell retention systems benefit from a selective synthetic membrane to retain cells and specific compounds in the bioreactor while allowing other soluble compounds to pass freely through the membrane. This separation occurs either due to the convection caused by pressure difference over the membrane as the driving force or diffusion of specific compounds due to concentration gradient built over the membrane layer. The selective behavior depends on the membrane characteristics such as pore size and morphology, membrane charge, affinity, and hydrophobicity. Although membrane bioreactors (MBRs) have long been used for wastewater treatment purposes, integration of MBR technology in biological processes is not fully developed at the industrial scale. By the application of MBRs in bioconversion processes, high concentrations of active microorganisms can be retained in the bioreactor and cell washout can be eliminated during continuous processes. This ease of continuous operation guarantees higher productivity rates [26]. Moreover, solid retention time can be controlled independently from hydraulic retention time [20]. Additionally, as the feeding and removal of metabolites can be controlled, metabolites of a specific stage of bioconversion can be removed from the bioreactor to suppress substrate or product inhibition.

This study aimed at finding a feasible approach for production and recovery of VFAs from excess sludge and food waste for further application in the denitrification stage of WWT. In this regard, a novel semi-continuous membrane-assisted process was designed to produce and recover VFAs from excess sewage sludge and food waste slurry. Furthermore, in order to facilitate sludge and food waste hydrolysis, inhibit methane formation, and enhance VFAs yield and volumetric productivity, a series of different pretreatment approaches (thermal, thermochemical, etc.), batch anaerobic digestion conditions (initial $\mathrm{pH}$, substrates types, etc.), and continuous VFAs fermentation using long-term immersed MBR were taken into consideration. Finally, the economic feasibility of retrofitting MBRs into the wastewater treatment process and the potential of the application of produced VFAs as a bio-based carbon source, replacing the conventional fossil-based methanol, to meet denitrification demands in a WWTP is analyzed.

\section{Materials and Methods}

\subsection{Substrate and Seeding Inoculum}

As substrates, this study used the excess sewage sludge (ESS) and food waste slurry (FWS) collected from a wastewater treatment plant Gryaab AB (Gothenburg, Sweden) and a solid waste treatment company Renova AB (Gothenburg, Sweden), respectively. The food waste slurry was prepared from food wastes collected from households and retailers within Gothenburg municipality, was diluted using $20 \%$ water, and screw pressed through a $10 \mathrm{~mm}$ mesh. The substrates were stored in a freezer and thawed in a cold room $\left(4-5^{\circ} \mathrm{C}\right)$ prior to use as feed in the bioreactors. The main characterization data for these substrates are provided in Table 1.

Table 1. Characteristics of the excess sewage sludge and food waste slurry.

\begin{tabular}{ccc}
\hline Property & Excess Sewage Sludge & Food Waste Slurry \\
\hline $\mathrm{pH}$ & $6.0 \pm 0.10$ & $4.1 \pm 0.04$ \\
$\mathrm{TSS}(\mathrm{g} / \mathrm{L})$ & $61.6 \pm 0.92$ & $131.9 \pm 1.09$ \\
$\mathrm{VSS}(\mathrm{g} / \mathrm{L})$ & $38.3 \pm 0.71$ & $125.5 \pm 1.02$ \\
Total COD $(\mathrm{g} / \mathrm{L})$ & $80.5 \pm 2.50$ & $217.0 \pm 1.00$ \\
Soluble COD $(\mathrm{g} / \mathrm{L})$ & $5.35 \pm 0.15$ & $86.00 \pm 0.50$ \\
$\mathrm{NH}_{4}{ }^{+}-\mathrm{N}(\mathrm{g} / \mathrm{L})$ & $0.86 \pm 0.02$ & $0.49 \pm 0.01$ \\
$\mathrm{PO}_{4}{ }^{3-}-\mathrm{P}(\mathrm{g} / \mathrm{L})$ & $0.04 \pm 0.00$ & $1.02 \pm 0.00$ \\
\hline
\end{tabular}

The granulated bacteria used as inoculum for the batch reactors were collected from an upflow anaerobic sludge blanket reactor treating municipal wastewater (Hammarby Sjöstad, Stockholm, Sweden). The fermentation broth from another study by our group [27] was used as inoculum seed for the immersed membrane bioreactors (iMBRs). 


\subsection{Experimental Set-Up}

\subsubsection{Thermal and Thermochemical Pretreatment}

Thermal pretreatment was performed on both food waste slurry and excess sewage sludge at three different temperatures: 70,90 , and $100^{\circ} \mathrm{C}$. Each different pretreatment case was operated at different durations between $30 \mathrm{~min}$ to $4 \mathrm{~h}$. A quantity of $12.5 \mathrm{~mL}$ of the substrate (food waste slurry or excess sewage sludge) was added to a $100 \mathrm{~mL}$ glass bottle and tap water added to have a final volume of $50 \mathrm{~mL}$. A water bath shaker was used to set the temperature at the designated point. For the thermochemical pretreatment of both substrates the following conditions with different ranges were tested: alkali $\mathrm{NaOH} / \mathrm{Ca}(\mathrm{OH})_{2}$, temperature $70 / 90{ }^{\circ} \mathrm{C}$, and duration $30 \mathrm{~min}$ to $4 \mathrm{~h}$. A total of $12.5 \mathrm{~mL}$ substrate was added to a $100 \mathrm{~mL}$ glass bottle and the required dose of alkali was added to have $\mathrm{pH}$ level 12; then, tap water was added to have the final volume of $50 \mathrm{~mL}$. For the pretreatment, adequate amounts of $4 \mathrm{M} \mathrm{NaOH}$ solution and $\mathrm{Ca}(\mathrm{OH})_{2}$ powder were used in respective experiments to reach a $\mathrm{pH}$ level of 12. A water bath shaker was used to have the desired temperature. The soluble chemical oxygen demand (sCOD) of ESS and FWS were measured after each pretreatment and compared with the initial SCOD values. The increase in SCOD was reported as percentage of the initial SCOD values. The desirable pretreatment for subsequent acidogenic fermentation was selected based on an increase in sCOD of substrate after pretreatment.

\subsubsection{Batch Set-Up}

The effect of pretreatment on the acidogenic fermentation of the excess sewage sludge and food waste slurry was evaluated in batch mode using $120 \mathrm{~mL}$ serum glass bottles as the reactor. Each reactor was fed with $1 \mathrm{~g}$ VS substrate and $0.33 \mathrm{~g}$ VS inoculum seed. The volume of each reactor was fixed at $50 \mathrm{~mL}$ by adding tap water. Then, the $\mathrm{pH}$ of each reactor was set to the designated level. Finally, reactors were sealed by using aluminum caps with a rubber stopper and purged with nitrogen for approximately $2 \mathrm{~min}$ to achieve anaerobic conditions. The reactors were incubated at $37^{\circ} \mathrm{C}$ and $120 \mathrm{rpm}$ in a water bath shaker. The combination of the following conditions was tested in the batch set-up in three replicates: food waste, excess sewage sludge, pretreated food waste, pretreated excess sewage sludge, and initial pH levels 5, 8, 10, and 12. Two blanks were used, one containing seed inoculum and the other containing excess sewage sludge.

\subsubsection{Immersed Membrane Bioreactor (iMBR) Set-Up}

Two semi-continuous processes were operated for VFA production and recovery without external control of $\mathrm{pH}$ or substrate pretreatment. Each process consisted of a continuous stirred tank reactor (BBI biotech, Berlin, Germany) with $2 \mathrm{~L}$ working volume, equipped with a radial impeller (BBI biotech, Berlin, Germany), and an immersed flat-sheet membrane panel.

The membrane used in this work was a custom-made 2nd generation Integrated Permeate Channel (IPC) membrane panel (VITO NV, Mol, Belgium) with double filtration layers and effective area of $68.6 \mathrm{~cm}^{2}$. The filtration layers were cast on a polyester spacer-fabric, which made it suitable for the application of backwash. The mean pore size of the membrane was $\sim 0.3 \mu \mathrm{m}$. The IPC membrane had inbuilt gas channels with 6 diffusers on each side of the panel for scouring the membrane surface during the filtration cycle. For membrane cleaning purposes nitrogen gas was sparged through membrane diffusers. The permeate channel was connected to a peristaltic pump (Watson Marlow, Wilmington, UK). Ultrasonic flowmeter (Atrato, Titan Enterprises, Sherborne, UK) and stand-alone volumetric gas flow meter ( $\mu$ FLOW, Bioprocess Control AB, Lund, Sweden) were used for measuring the permeate flow and volume of produced gas, respectively. The filtration cycle included a $2 \mathrm{~min}$ filtration followed by $30 \mathrm{~s}$ of backwash which were operated automatically by using an electric relay (Zelio Logic SR2A101BD, Schneider Electric Automation GmbH, Marktheidenfeld, Germany). The schematic diagram of the set-up is presented in Figure 3. 


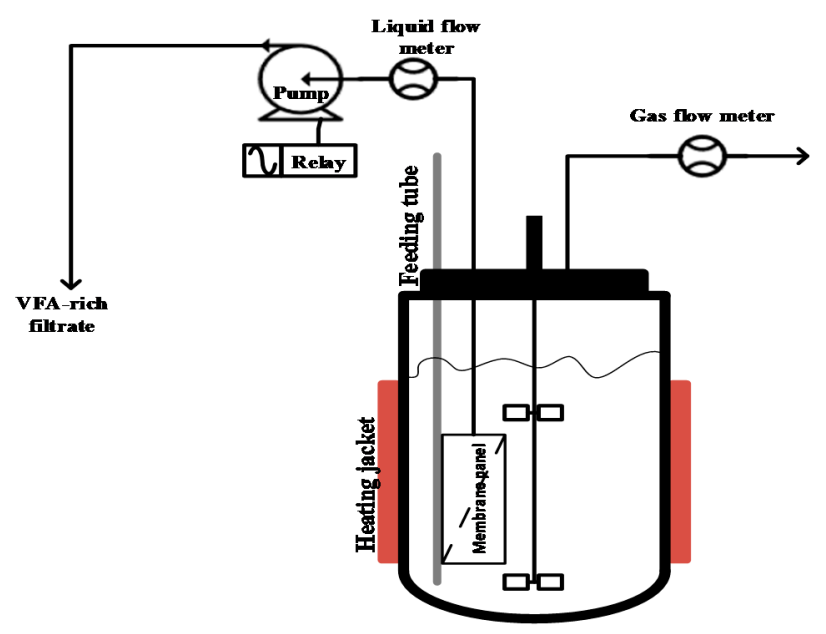

Figure 3. Schematic diagram of the semi-continuous set-up.

Each reactor was inoculated with $800 \mathrm{~mL}$ inoculation broth and $0.2 \mathrm{gVS} / \mathrm{L}$ of the substrate (one reactor with non-pretreated food waste slurry and another one with non-pretreated excess sewage sludge). Subsequently, tap water was added to each reactor to have a working volume of $2 \mathrm{~L}$. Finally, each reactor was sealed and purged with nitrogen gas for five minutes to have the anaerobic conditions. The temperature and impeller mixing speed were set at $37^{\circ} \mathrm{C}$ and $100 \mathrm{rpm}$, respectively. The acclimatization of the seed inoculum was conducted in the main reactors for 34 days with the organic loading rate (OLR) of $0.2 \mathrm{gVS} / \mathrm{L} /$ day. The actual fermentation was started, after which the bioreactors were operated at an OLR of $1 \mathrm{gVS} / \mathrm{L} /$ day for 30 days. Then, the OLR was raised to $3 \mathrm{gVS} / \mathrm{L} /$ day for the remaining fermentation period. The mode of operation was semi-continuous, which was carried out by filtration cycle followed by feeding reactor on a daily basis.

\subsection{Analytical Method}

The total solids (TS), suspended solids (SS), VS, ammonium-nitrogen $\left(\mathrm{NH}^{+}-\mathrm{N}\right)$, total chemical oxygen demand (tCOD), and soluble chemical oxygen demand (sCOD) concentrations were measured according to standard methods [28]

The gas samples were taken by a $250 \mu \mathrm{L}$ gas-tight syringe (VICI, Precision Sampling Inc., Baton Rouge, LA, USA) daily and were analyzed using a gas chromatograph (Perkin-Elmer, Norwalk, CT, USA) with a thermal conductivity detector and equipped with a packed column (CarboxenTM 1000, SUPELCO, $6^{\prime} \times 1.8^{\prime \prime} \mathrm{OD}, 60 / 80 \mathrm{Mesh}$, Shelton, CT, USA). The injection temperature was $200^{\circ} \mathrm{C}$ and nitrogen used as the carrier gas with a flow rate of $30 \mathrm{~mL} / \mathrm{min}$ at $75^{\circ} \mathrm{C}$. The VFAs were analyzed by High-Performance Liquid Chromatography (Waters 2695, Waters Corporation, Milford, MA, USA) equipped with a hydrogen-ion based ion exchange column (Aminex HPX87-H, BioRad Laboratories, München, Germany) at $60{ }^{\circ} \mathrm{C}$ and with $0.6 \mathrm{~mL} / \mathrm{min} 5 \mathrm{mM} \mathrm{H}_{2} \mathrm{SO}_{4}$ as eluent. An ultraviolet (UV) absorbance detector (Waters 2487, Waters Corporation, Milford, MA, USA), at $210 \mathrm{~nm}$ wavelength, was used to measure the concentration of different VFAs in the samples.

\subsection{Statistical Analysis}

All pretreatment and batch fermentation experiments in this study were carried out in triplicate. Average values are reported in the text and graphs are illustrating the average values plus error bars for two standard deviations. MINITAB ${ }^{\circledR} 17$ (Minitab Ltd., Coventry, UK) was used for statistically analyzing the data. The one-way analysis of variance (ANOVA) with a confidence interval of $95 \%$ was used to analyze the data. 


\subsection{Process Feasibility Study}

The main purpose of the application of the iMBR set-up for the production of VFAs from food waste and excess sludge was the provision of the carbon source required for denitrification purposes in the WWT process. In this regard, two hypothetic scenarios were considered for the application of excess sludge and food waste as the substrate for VFAs production using the iMBR. The ultimate goal for both scenarios was to replace methanol used during denitrification with VFA permeate from the iMBR. The data used as the basis for the calculations and further comparison of different cases are based on actual average data provided by Gryaab AB (Gothenburg, Sweden) for a WWTP with processing stages presented in Figure 4. Figure 4 also considers the base scenario for the treatment of food waste for biogas production.

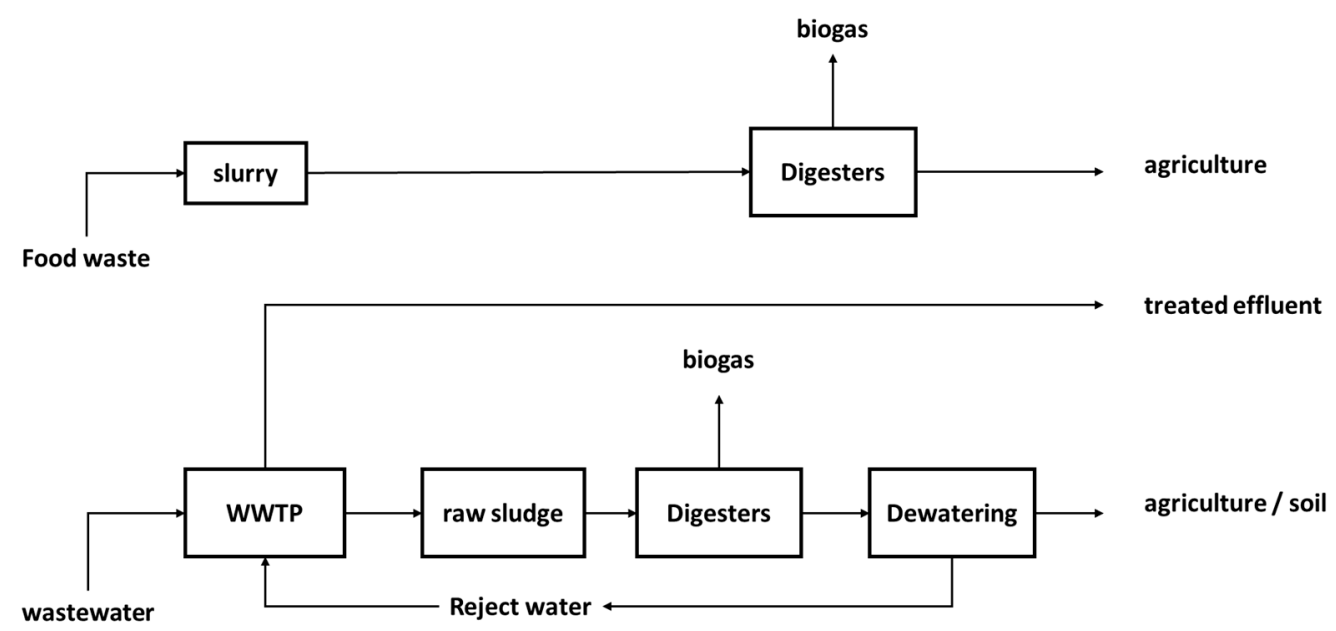

Figure 4. An overview of the processing stages of the base WWTP and food waste treatment facility.

The two scenarios for the integration of iMBRs into the VFAs production process using food waste and excess sludge are presented in Figures 5 and 6 . In this scenarios, VFAs production from FWS and ESS in two AD MBRs working at an OLR of $3 \mathrm{gVS} / \mathrm{L} /$ day, hydraulic retention time of 10 days, and filtration flux of $7.5 \mathrm{~L} / \mathrm{m}^{2} / \mathrm{h}$ were considered. In this regard, the economic feasibility calculations on the capital and operational expenses were made for conditions that the VFA solution obtained as permeate is fed as an external carbon source to the denitrification stage for complete replacement of the conventionally used methanol.

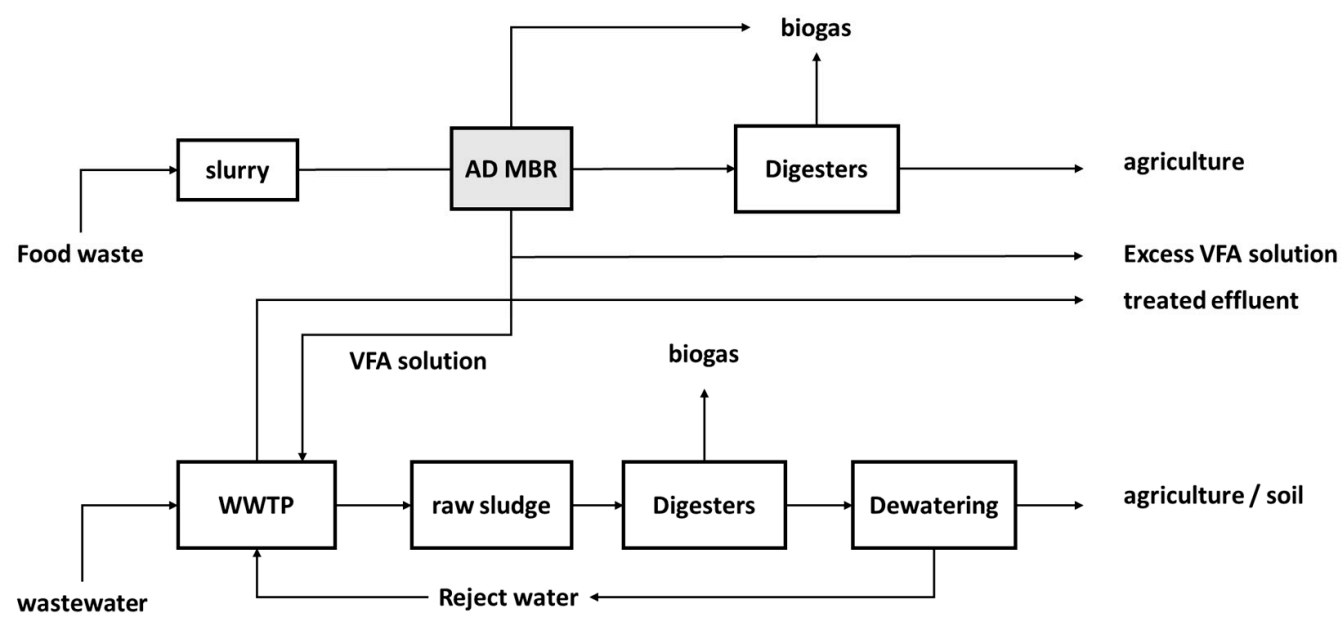

Figure 5. An overview of the proposed scenario one. 


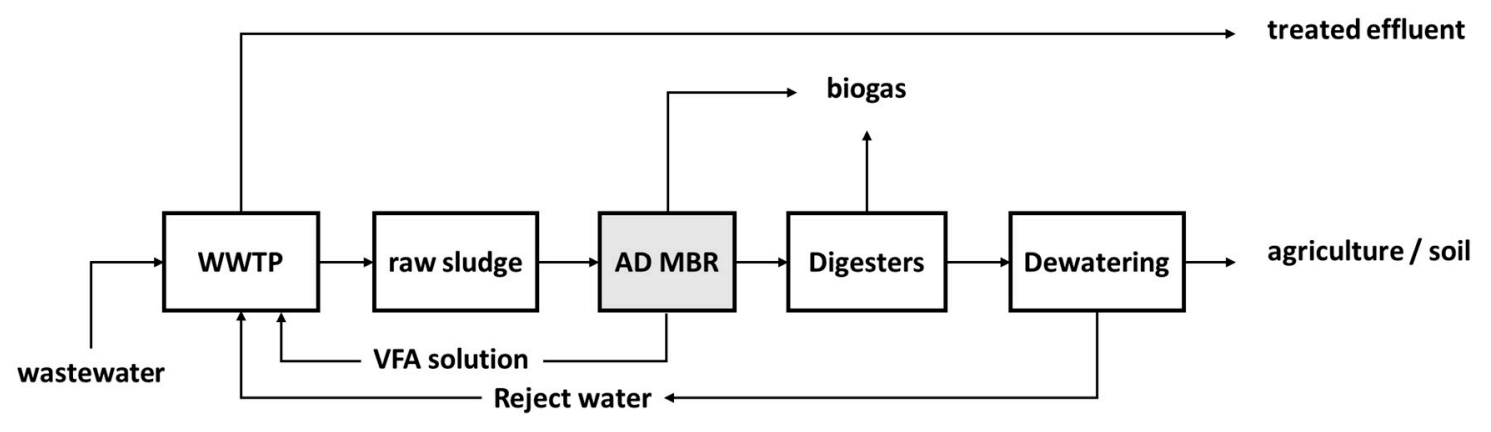

Figure 6. An overview of the proposed scenario two.

In order to have a general understanding of the economic feasibility of applying either of the scenarios to provide the required amounts of VFAs for methanol replacement, the following main parameters were considered in the estimation: membrane price $\left(100 € / \mathrm{m}^{2}\right)$, scouring gas demand per unit area of membrane per time $\left(0.09 \mathrm{Nm}^{3} / \mathrm{m}^{2} . \mathrm{h}\right)$, specific energy demand for gas sparging $\left(0.04 \mathrm{kWh} / \mathrm{m}^{3}\right)$, membrane life (8 years), electrical energy cost $(0.08 € / \mathrm{kWh})$, blower energy constant (6.5), and cost of chemical cleaning solution $\left(0.01 € / \mathrm{m}^{3}\right.$ based on $\mathrm{NaOCl}$ and citric acid). Considering the mentioned factors, the operation expenses for the applied MBR ranges between $0.13-0.35$ euros per cubic meter of recovered permeate. The average process values are presented in the tables in Section 3.4. The prices noted for methanol and VFAs are average prices acquired in 2018 (provided by Gryaab AB and other suppliers).

\section{Results and Discussion}

\subsection{Effect of Thermal and Thermochemical Pretreatment on Substrate Solubilization}

Thermal and thermochemical pretreatments with different conditions were applied to excess sewage sludge and food waste slurry. The sCOD of pretreated materials, as it can reflect the effectiveness of the pretreatment method in substrate solubilization, are reported in Figure 7. As can be observed from the figure, the result of thermal pretreatment at 70 and $90^{\circ} \mathrm{C}$ for excess sewage sludge was similar. The sCOD of the substrate almost doubled, which accounted for roughly $20 \%$ of the excess sewage sludge tCOD, after $30 \mathrm{~min}$ of pretreatment; however, this increase did not change significantly during the $4 \mathrm{~h}$ of pretreatment. This suggested that increasing temperature from 70 to $90{ }^{\circ} \mathrm{C}$ or increasing exposure time from $30 \mathrm{~min}$ to $4 \mathrm{~h}$ does not affect thermal pretreatment. Xue, et al. [29] reported that thermal pretreatment at 70 and $90{ }^{\circ} \mathrm{C}$ led to similar increases in SCOD at short pretreatment duration (less than $12 \mathrm{~h}$ ), however, pretreatment at $90{ }^{\circ} \mathrm{C}$ with duration more than $24 \mathrm{~h}$ showed better results. In the case of food waste slurry, both temperature and exposure time influence thermal pretreatment effectiveness. Thermal pretreatment at $90{ }^{\circ} \mathrm{C}$ was more effective compared to pretreatment at $70{ }^{\circ} \mathrm{C}$ as the increase in sCOD was between $18-33 \%$ for the $90{ }^{\circ} \mathrm{C}$ pretreatment and $6-21 \%$ for the $70{ }^{\circ} \mathrm{C}$ pretreatment at different contact times, respectively. Regarding thermochemical pretreatment of substrates, pretreatment with $\mathrm{Ca}(\mathrm{OH})_{2}$ at 70 and $90{ }^{\circ} \mathrm{C}$ for both excess sewage sludge and food waste slurry resulted in similar increases in SCOD compared to thermal pretreatment at respective temperatures. However, pretreatment with $\mathrm{NaOH}$ showed significant increases $(p<0.05)$ in sCOD. Similarly, Penaud, et al. [30] and Kim, et al. [31] reported that thermochemical pretreatment with $\mathrm{Ca}(\mathrm{OH})_{2}$ is less effective for solubilizing the biomass compared to $\mathrm{NaOH}$. This could be due to the low solubility of $\mathrm{Ca}(\mathrm{OH})_{2}$ in water. Pretreating excess sewage sludge with $\mathrm{NaOH}$ at 70 and $90{ }^{\circ} \mathrm{C}$ for $30 \mathrm{~min}$ resulted in 5.30- and 6.35-times increases in SCOD, respectively. Exposure time did not affect the pretreatment at $90{ }^{\circ} \mathrm{C}$ considerably but had an impact on pretreatment at $70{ }^{\circ} \mathrm{C}$ as the sCOD of pretreated sludge increased from $28.4 \mathrm{~g} / \mathrm{L}$ after $30 \mathrm{~min}$ to $37.2 \mathrm{~g} / \mathrm{L}$ after $4 \mathrm{~h}$ of pretreatment. Thermal and thermochemical pretreatment improved the disintegration of both excess sewage sludge and food waste slurry; however, this does not necessarily lead to improvement of the further biodegradation, 
since other compounds such as heavy metals, inhibitors, and high complex compounds can be released in the water phase. Thus it is necessary to evaluate the effect of pretreatment on the anaerobic digestion. Considering the results of the pretreatment step, industrial and economic aspects of the pretreatment method, using both thermal and thermochemical $(\mathrm{NaOH})$ pretreatment at $90^{\circ} \mathrm{C}$ for $30 \mathrm{~min}$, were chosen for the next phase of the experiment.

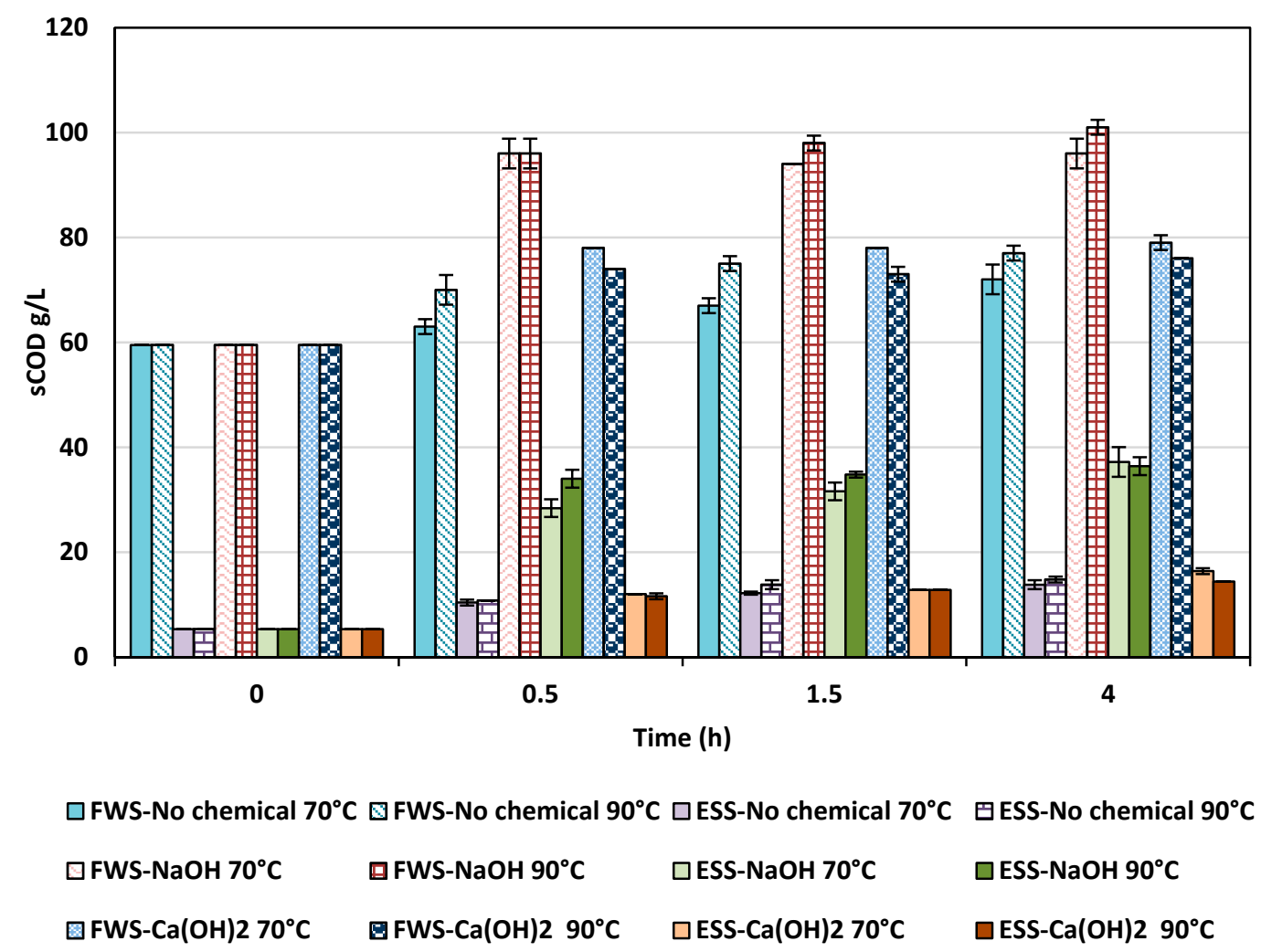

Figure 7. The changes in the sCOD of the non-pretreated, chemically, and thermochemically pretreated excess sewage sludge and food waste slurry. (Chemicals: $\mathrm{NaOH}$ and $\mathrm{Ca}(\mathrm{OH})_{2}$, temperatures: 70 and $\left.90{ }^{\circ} \mathrm{C}\right)$.

\subsection{Effect of Pretreatment and Initial $p H$ on VFAs Production in Batch Fermentation}

Effects of the chosen thermal $\left(90^{\circ} \mathrm{C}\right.$ for $\left.30 \mathrm{~min}\right)$, thermochemical pretreatments $\left(90^{\circ} \mathrm{C}\right.$ and $\mathrm{NaOH}$ for $30 \mathrm{~min})$, and initial $\mathrm{pH}(5,8,10$, and 12) on VFAs production from excess sewage sludge and food waste slurry were evaluated in batch reactors and the total VFAs concentrations. The averages of three replicates are reported in Figure 8.

For the excess sewage sludge without pretreatment as the substrate, the highest total VFAs concentration at the end of the fermentation (day 25) occurred at $\mathrm{pH} 12$ with the value $14.73 \mathrm{~g} / \mathrm{L}$ (VFAs yield of $0.46 \mathrm{~g} \mathrm{VFA} / \mathrm{g}$ VS by day 25) followed by $9.73 \mathrm{~g} / \mathrm{L}$, at $\mathrm{pH} 5$. The total VFAs concentration was almost zero for $\mathrm{pH} 8$ and 10 on day 25. The final pH levels of the reactors are reported in Table 2. The $\mathrm{pH}$ in reactors with initial $\mathrm{pH}$ levels of 8 and 10 dropped to 7.3, which made the system more suitable for biogas production [32]. Thus, the reason for the low level of VFAs in the system could be due to their conversion to biogas. These results seem reasonable given the gas production data (Figure 9). The accumulated biogas volume at $\mathrm{pH} 8$ was $177.9 \mathrm{~mL}$ ( $58.17 \%$ methane) which is almost 14 times the biogas volume at either $\mathrm{pH} 5$ or 12 . The accumulated biogas volume at $\mathrm{pH} 10$ was $88.59 \mathrm{~mL}$ with $67.77 \%$ methane content. 

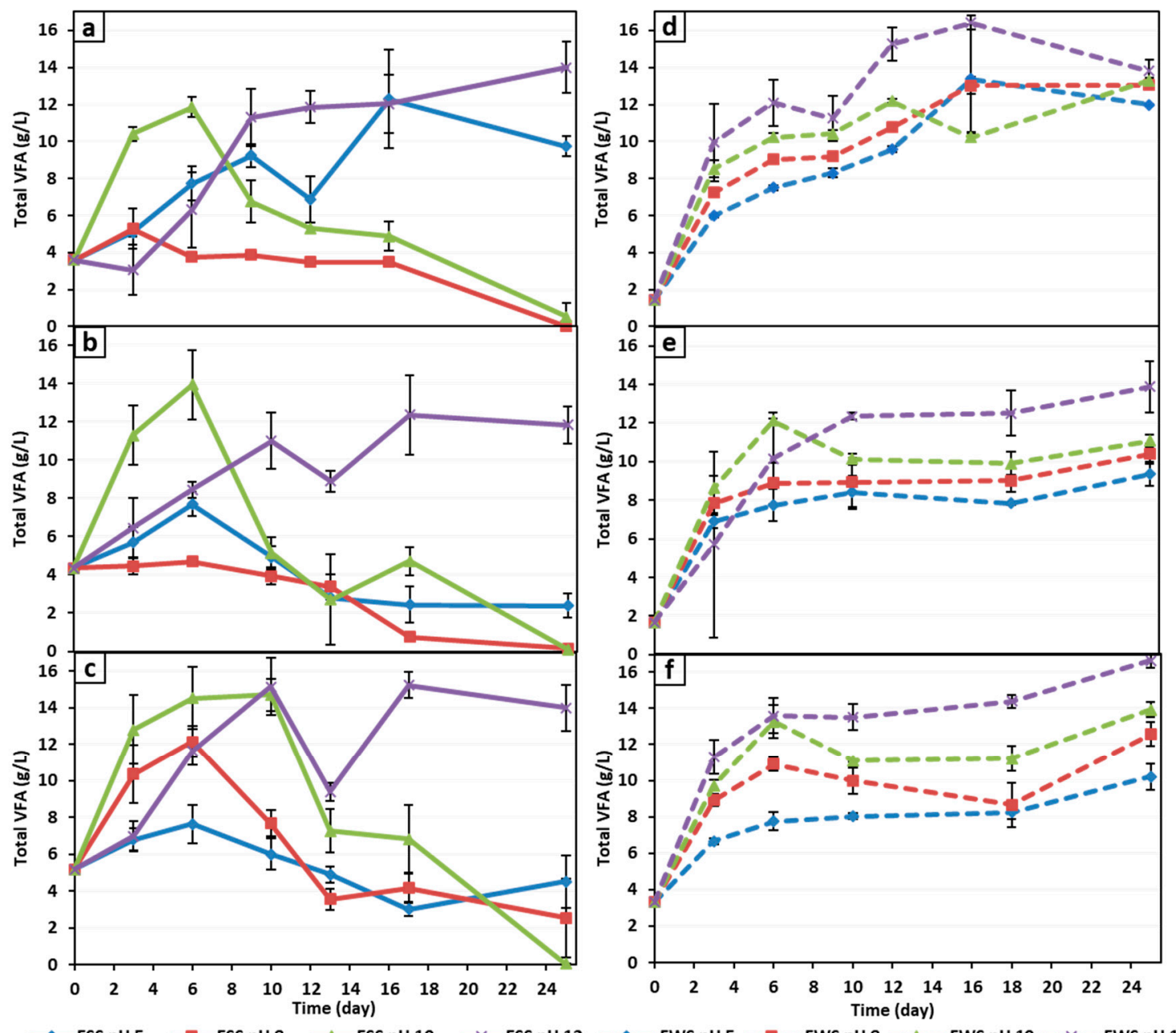

$\rightarrow$ ESS pH 5

- ESS pH 8

ESS pH 10

$(a, d)$ no pretreatment, $(b, e)$ thermal pretreatment and $(c, f)$ thermochemical pretreatment

Figure 8. Effect of pretreatment on VFAs production from excess sewage sludge and food waste slurry.

Similar to the case of excess sewage sludge without pretreatment, the highest final total VFA concentration for the thermally pretreated excess sewage sludge was achieved at $\mathrm{pH} 12$ with value $11.83 \mathrm{~g} / \mathrm{L}$, although the maximum VFAs concentration during the fermentation, $13.94 \mathrm{~g} / \mathrm{L}$, belonged to $\mathrm{pH} 10$ at day 6 (Figure 8b). The VFAs accumulation trend at $\mathrm{pH} 8,10$, and 12 were quite similar to the trend of not pretreated excess sewage sludge but the trend at $\mathrm{pH} 5$ was totally different. The total VFA concentration at pH 5 increased till day 6 and reached its maximum, $7.68 \mathrm{~g} / \mathrm{L}$, and thereafter decreased gradually until the end of fermentation (day 25). The final total concentration was $2.38 \mathrm{~g} / \mathrm{L}$, roughly $20 \%$ amount of the VFAs from not pretreated excess sewage sludge at $\mathrm{pH} 5$. The accumulated biogas volume at $\mathrm{pH} 5$ was $69 \mathrm{~mL}$ compared to $13 \mathrm{~mL}$ from not pretreated excess sewage sludge. This huge increase in biogas production indicated that the lower amount of VFAs was due to their conversion to biogas. The $\mathrm{pH}$ at the end of fermentation was 6.72, which is suitable for biogas production. Comparing the amount of $\mathrm{NH}_{4}{ }^{+}-\mathrm{N}$ in the thermally pretreated excess sewage sludge system with the not pretreated excess sewage sludge system suggests that a higher $\mathrm{NH}_{4}{ }^{+}-\mathrm{N}$ amount provides higher buffering capacity that maintains the $\mathrm{pH}$ for better biogas production. For instance, the $\mathrm{NH}_{4}{ }^{+}-\mathrm{N}$ amounts for the system with thermally pretreated excess sewage sludge and the system with non-pretreated excess sewage sludge at day 9 were $813.33 \mathrm{mg} / \mathrm{L}$ and $206.66 \mathrm{mg} / \mathrm{L}$, respectively. Zhai, et al. [33] reported that in anaerobic digestion VFAs in the system could be neutralized by proper $\mathrm{NH}_{4}{ }^{+}-\mathrm{N}$ concentration. 
Table 2. Batch reactors' initial $\mathrm{pH}$, final $\mathrm{pH}$, and gas products volume.

\begin{tabular}{|c|c|c|c|c|c|}
\hline Pretreatment Mode & Substrate & Initial pH & Final pH & $\begin{array}{l}\text { Total Gas Produced } \\
(\mathrm{mL})\end{array}$ & Methane (mL) \\
\hline \multirow{8}{*}{ No pretreatment } & \multirow{4}{*}{ excess sewage sludge } & 5 & $5.09 \pm 0.03$ & $13.0 \pm 0.5$ & $8.9 \pm 0.6$ \\
\hline & & 8 & $7.30 \pm 0.02$ & $177.9 \pm 4.2$ & $103.5 \pm 4.1$ \\
\hline & & 10 & $7.37 \pm 0.03$ & $88.6 \pm 9.7$ & $60.0 \pm 9.9$ \\
\hline & & 12 & $8.30 \pm 0.60$ & $11.5 \pm 4.3$ & $0.7 \pm 0.3$ \\
\hline & \multirow{4}{*}{ food waste slurry } & 5 & $4.38 \pm 0.02$ & $38.0 \pm 2.3$ & $8.2 \pm 1.1$ \\
\hline & & 8 & $4.50 \pm 0.00$ & $89.7 \pm 14.2$ & $9.2 \pm 0.5$ \\
\hline & & 10 & $4.66 \pm 0.02$ & $111.3 \pm 1.4$ & $10.5 \pm 0.5$ \\
\hline & & 12 & $4.97 \pm 0.03$ & $34.4 \pm 5.3$ & $2.8 \pm 0.9$ \\
\hline \multirow{8}{*}{$\begin{array}{l}\text { Thermal } \\
\text { pretreatment at } 90^{\circ} \mathrm{C} \\
\text { for } 30 \mathrm{~min}\end{array}$} & \multirow{4}{*}{ excess sewage sludge } & 5 & $6.72 \pm 0.06$ & $69.0 \pm 3.6$ & $8.4 \pm 1.8$ \\
\hline & & 8 & $7.37 \pm 0.01$ & $78.7 \pm 22.6$ & $48.6 \pm 3.6$ \\
\hline & & 10 & $7.51 \pm 0.04$ & $100.2 \pm 3.9$ & $16.9 \pm 1.9$ \\
\hline & & 12 & $9.38 \pm 0.06$ & $19.0 \pm 6.4$ & $0.9 \pm 0.3$ \\
\hline & \multirow{4}{*}{ food waste slurry } & 5 & $4.87 \pm 0.13$ & $94.2 \pm 16.6$ & $8.4 \pm 0.2$ \\
\hline & & 8 & $5.09 \pm 0.11$ & $108.1 \pm 11.2$ & $12.5 \pm 0.8$ \\
\hline & & 10 & $5.18 \pm 0.08$ & $88.2 \pm 39.2$ & $2.6 \pm 1.0$ \\
\hline & & 12 & $5.19 \pm 0.14$ & $62.3 \pm 8.7$ & $2.7 \pm 2.3$ \\
\hline \multirow{8}{*}{$\begin{array}{l}\text { Pretreatment with } \\
\mathrm{NaOH} \text { at } 90^{\circ} \mathrm{C} \text { for } \\
30 \mathrm{~min}\end{array}$} & \multirow{4}{*}{ excess sewage sludge } & 5 & $6.65 \pm 0.03$ & $85.6 \pm 12.1$ & $5.7 \pm 0.6$ \\
\hline & & 8 & $7.21 \pm 0.09$ & $81.4 \pm 6.1$ & $18.9 \pm 1.2$ \\
\hline & & 10 & $7.48 \pm 0.05$ & $35.7 \pm 7.4$ & $9.6 \pm 1.4$ \\
\hline & & 12 & $9.29 \pm 0.03$ & $7.3 \pm 2.8$ & $1.6 \pm 0.5$ \\
\hline & \multirow{4}{*}{ food waste slurry } & 5 & $4.87 \pm 0.08$ & $68.4 \pm 12.9$ & $6.4 \pm 1.3$ \\
\hline & & 8 & $5.09 \pm 0.02$ & $98.0 \pm 11.8$ & $12.0 \pm 1.8$ \\
\hline & & 10 & $5.18 \pm 0.02$ & $87.6 \pm 3.7$ & $3.8 \pm 0.8$ \\
\hline & & 12 & $5.19 \pm 010$ & $87.0 \pm 4.0$ & $6.8 \pm 1.4$ \\
\hline
\end{tabular}

Total VFAs concentration trends for fermentation with thermochemically pretreated excess sewage sludge were quite similar to trends of VFAs from thermally pretreated excess sewage sludge, however, the final total VFAs concentration was slightly higher. The final total VFAs concentration was $13.99 \mathrm{~g} / \mathrm{L}$ at $\mathrm{pH} 12$ (Figure 8c). Comparing the total VFAs concentrations (Figure 8a-c) indicates that pretreatment did not improve the accumulation of VFAs in the system in most $\mathrm{pH}$ levels; even in the case of $\mathrm{pH} 5$, it reduced total VFAs significantly.

In the anaerobic digestion with non-pretreated food waste slurry, the highest total VFAs concentration was $16.40 \mathrm{~g} / \mathrm{L}$ and obtained at $\mathrm{pH} \mathrm{12,} \mathrm{day} \mathrm{16.} \mathrm{The} \mathrm{rate} \mathrm{of} \mathrm{VFAs} \mathrm{accumulation} \mathrm{during} \mathrm{the}$ initial days was higher at higher alkalinity; for instance, it was highest at $\mathrm{pH} 12$ and the highest yield of VFAs at the end of fermentation (0.558 g VFA/g VS) was obtained at this $\mathrm{pH}$. Hussain et al. [34] similarly reported higher VFAs yield at higher $\mathrm{pH}$. The accumulated amount of produced methane in each $\mathrm{pH}$ was less than $10 \mathrm{~mL}$ (approximately $8-20 \%$ of total biogas). The final $\mathrm{pH}$ of reactors was less than 5 in all reactors (Table 2) which can explain the low methane production due to inhibition of methanogens at low $\mathrm{pH}$.

The VFAs accumulation trend for both thermally and thermochemically pretreated food waste slurry was similar (Figure 8d-f)). Total VFAs concentration ramped up during the initial days and after that increased gradually until the last day of fermentation. The final total VFAs concentration for the thermochemically pretreated food waste slurry at each $\mathrm{pH}$ level was higher than the final values for thermally pretreated food waste slurry at respective $\mathrm{pH}$ levels. However, except for $\mathrm{pH} 12$, the final total VFAs concentration at all other $\mathrm{pH}$ levels was lower than the values for the not pretreated food waste slurry. 

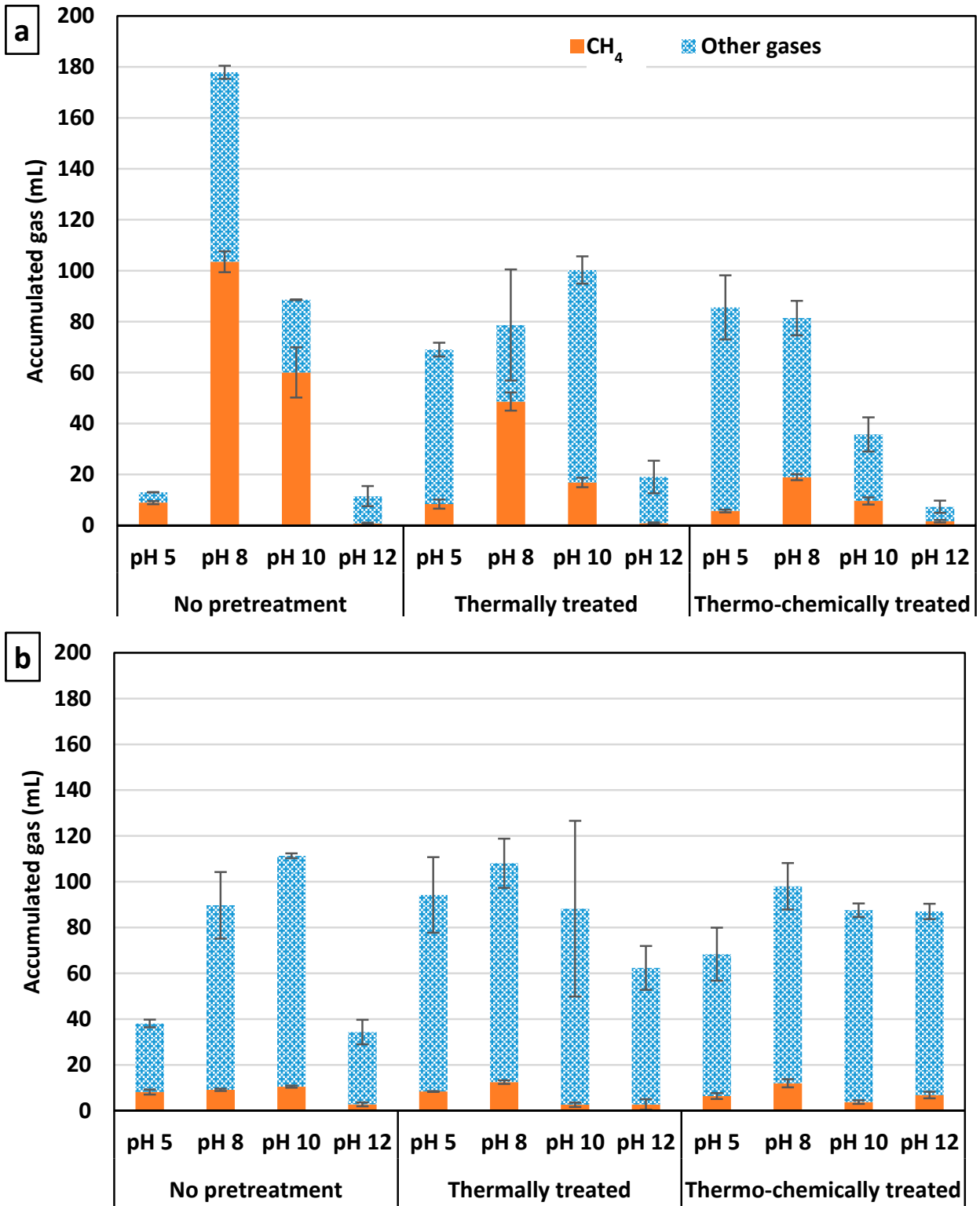

Figure 9. Biogas production from (a) excess sewage sludge and (b) food waste slurry in batch reactors for the different treatment methods at different $\mathrm{pH}$ levels.

The next phase of the experiment was designed based on the aforementioned results, however, the suggestion of an industrial partner was another factor for designing the process. Continuous VFAs production and recovery was conducted in an iMBR consisting of a flat-sheet membrane panel without external control of $\mathrm{pH}$ or substrate pretreatment. These conditions were selected in order to model an actual process that is easily implementable on a large scale. Process simplicity, lower energy demands, and lower usage of chemicals were the main concerns of the industrial partners. Thermochemical pretreatment is an energy and chemical-intensive process. In addition, during the batch fermentation, it was observed that pretreatment either reduced or had a low effect on final VFAs accumulation at most $\mathrm{pH}$ levels. Thus, excess sewage sludge and food waste slurry at an initial $\mathrm{pH}$ of 5 were used as feed during the iMBR fermentation and filtration.

\subsection{VFAs Production Using Immersed Membrane Bioreactor}

The highest total VFAs concentration was obtained at $\mathrm{pH} 12$ for both food waste slurry and excess sewage sludge without pretreatment, although obtaining $\mathrm{pH} 12$ resulted in substantial usage of 
chemicals (in this case $\mathrm{NaOH}$ ) and a higher risk of corrosion and other extra operational costs. Moreover, since the purpose of producing VFAs is using them as the carbon source for the denitrification step in the wastewater treatment process, the final product must contain a high soluble $\mathrm{C} / \mathrm{N}$ ratio. The highest final soluble $\mathrm{C} / \mathrm{N}$ ratio for the fermentation with the non-pretreated excess sewage sludge was 15.24, which occurred at $\mathrm{pH} 5$. For the fermentation with the non-pretreated food waste slurry, the $\mathrm{C} / \mathrm{N}$ ratio at $\mathrm{pH} 5$ was 48.45 , which was similar to that at $\mathrm{pH} 12$. As the final $\mathrm{C} / \mathrm{N}$ ratio was higher in $\mathrm{pH} 5$ and the final total VFAs concentration was close to values at $\mathrm{pH} 12$, and considering the long-run effect of the high alkalinity of the medium on chemical degradation of the polymeric membrane, the iMBR fermentation was conducted at initial $\mathrm{pH} 5$.

A stable fermentation system was established even after a considerably long period of operation of more than 3 months in total. The initial VFAs concentrations were $6.98 \mathrm{~g} / \mathrm{L}$ and $11.01 \mathrm{~g} / \mathrm{L}$ for excess sewage sludge and food waste slurry, respectively. During the whole period of feeding both reactors with OLR $1 \mathrm{gVS} / \mathrm{L} /$ day, the VFAs concentration declined, which indicates that the recovery rate of VFAs from the system was higher than the production rate. To boost the VFAs production, the OLR was increased to $3 \mathrm{gVS} / \mathrm{L} /$ day at day 31. As seen in Figure 10, at an organic loading rate of $3 \mathrm{gVS} / \mathrm{L} /$ day, the VFAs concentration in the reactor feeding with excess sewage sludge was ramped up till day 44 and reached $9.79 \mathrm{~g} / \mathrm{L}$. Thereafter, it leveled off until the last day of fermentation. A similar observation regarding a boost in acid production by increasing the OLR was reported by Wainaina et al. [27]. An average VFAs concentration of $9.8 \mathrm{~g} / \mathrm{L}$ was achieved from the excess sewage sludge at a yield of $0.38 \mathrm{gVFA} / \mathrm{g} \mathrm{VS}_{\text {added }}\left(533 \mathrm{mgCOD} / \mathrm{g} \mathrm{VS}_{\text {added }}\right)$, which is higher than the yield reported for uncontrolled $\mathrm{pH}$ systems and is comparable with systems with $\mathrm{pH}$ control. Longo et al. [18] reported a VFAs yield of $252 \mathrm{mg} \mathrm{COD} / \mathrm{g} \mathrm{VS}$ added for the system without any $\mathrm{pH}$ control and $398 \mathrm{mg} \mathrm{COD} / \mathrm{g} \mathrm{VS}$ added for the system with $\mathrm{pH}$ control at 10 using caustic soda. Moreover, the composition of VFAs produced by this iMBR is well suited for the denitrification process. It is important to analyze the composition of VFAs as different carbon sources have different denitrification efficiencies. For instance, the denitrification rate of acetic acid is double the value of propionic acid. The order of VFAs based on the denitrification rate from high to low is as follows: acetic acid, butyric acid, valeric acid, and propionic acid [17]. In the MBR fermentation solution, the most abundant VFA produced was acetic acid (53.90\% of total VFAs) followed by propionic acid ( $15.45 \%$ of total VFAs), while iso-valeric acid, butyric acid, iso-butyric, and valeric acid comprised $12.18 \%, 10.90 \%, 3.84 \%$, and $3.69 \%$ of total VFAs, respectively.

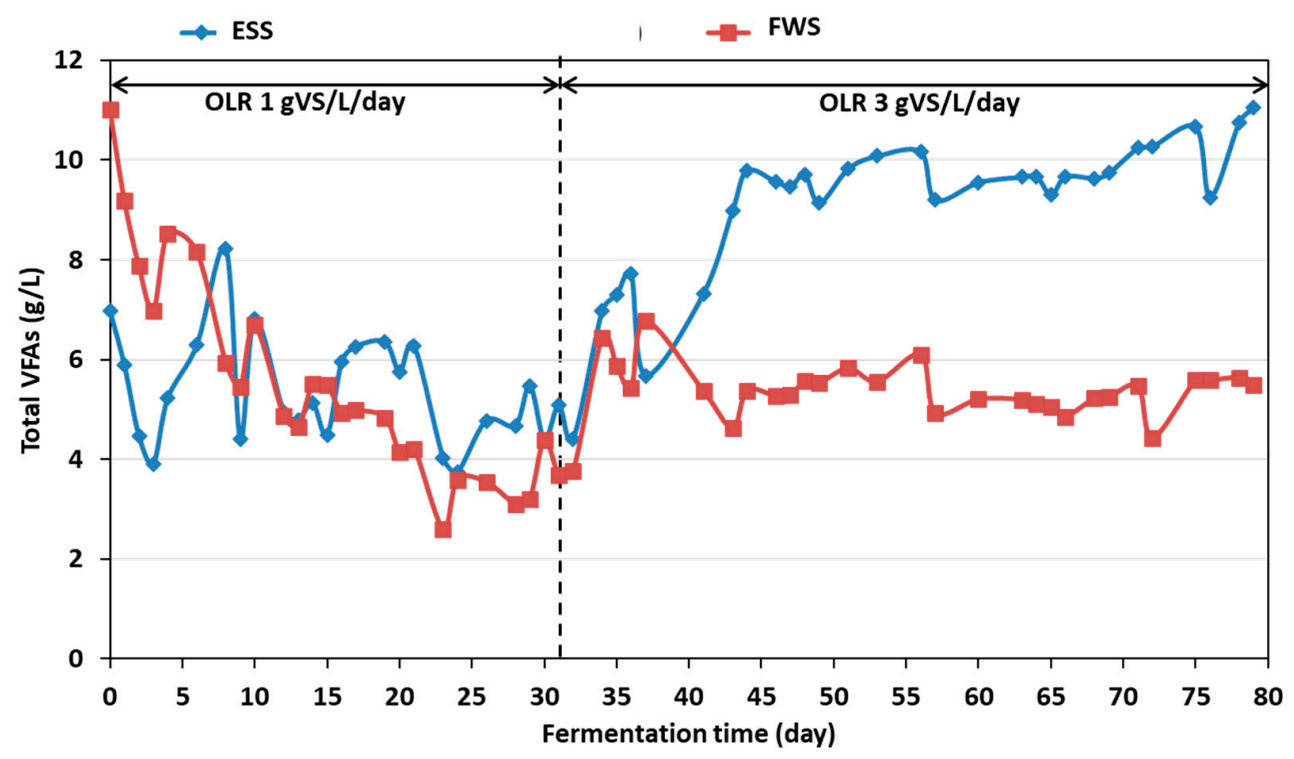

Figure 10. The concentration profiles of VFAs recovered from membrane bioreactors (MBRs) fed with excess sewage sludge and food waste slurry. 
On the other hand, using food waste as the substrate for AD MBR, a VFAs concentration of about $5.5 \mathrm{~g} / \mathrm{L}$ at a yield of $0.34 \mathrm{gVFA} / \mathrm{g} \mathrm{VS}$ added was obtained. Regarding food waste AD, our previous research has shown that high yields of up to $0.54 \mathrm{gVFA} / \mathrm{g} \mathrm{VS}$ added can be reached when the process conditions (mainly pH and OLR) are optimized in the MBR [9]. The average composition of the VFAs was as follows: acetic acid $42.63 \%$, propionic acid $17.29 \%$, iso-butyric acid $1.89 \%$, butyric acid $19.55 \%$, isovaleric acid $15.26 \%$, and valeric acid $3.34 \%$ of total VFAs. The composition of the VFAs is linked to the microbial structure in the bioreactor and the established microbial pathways [8]. In the prevailing operating conditions, the dominating bacteria community seemed to favor the biosynthesis of mainly acetic, butyric, and isovaleric acids. The presence of acetic and butyric acids is associated with pathways that result in hydrogen production [9]. On the other hand, the higher presence of isovaleric acid compared to valeric acid could have been caused by the bacterial dynamics in the bioreactor, although this phenomenon requires further investigation. With the considered process parameters, the AD of food waste resulted in excessive bio-hydrogen production $\left(244 \mathrm{NmL} / \mathrm{g} \mathrm{VS}_{\text {added }}\right)$ due to the favorable $\mathrm{pH}$ (about 5.2) compared to the $\mathrm{pH}$ condition maintained by the sludge, which was more suitable for VFAs production (about 5.9). The main gas by-product from the sludge fermentation was methane but at a low yield of approximately $93.6 \mathrm{NmL} / \mathrm{g} \mathrm{VS}$ added. The composition and volume of gas produced are presented in Figure 11. Regarding the $\mathrm{C} / \mathrm{N}$ ratios, the average values were 43.77 for food waste compared to 15.88 for sludge.

The concentration of suspended solids in the system can reflect the effectiveness of hydrolysis and acidification. Moreover, it directly affects the membrane filtration efficiency thorough membrane fouling. The viscosity of the fermentation broth is proportionate with the concentration of SS including the biomass and unhydrolyzed substrate. The high viscosity of the medium makes the membrane more susceptible to fouling [26]. During the feeding with OLR $1 \mathrm{gVS} / \mathrm{L} / \mathrm{day}$, the average concentration of suspended solids for the excess sewage sludge reactor and the food waste slurry reactor was $20.9 \mathrm{~g} / \mathrm{L}$ and $13.8 \mathrm{~g} / \mathrm{L}$, respectively. During that period the accumulation rate of SS in the reactor was $0.25 \mathrm{~g} / \mathrm{L} /$ day for the excess sewage sludge reactor while it was $0.09 \mathrm{~g} / \mathrm{L} /$ day for the food waste slurry reactor. After increasing the OLR to $3 \mathrm{gVS} / \mathrm{L} /$ day, in the excess sewage sludge reactor, the suspended solids concentration was increased to $30 \mathrm{~g} / \mathrm{L}$ in the first 10 days after changing OLR, however, thereafter, the suspended solids accumulation rate was decreased to $0.05 \mathrm{~g} / \mathrm{L} /$ day till the end of fermentation (Figure 12). Interestingly, the stable concentration level of VFAs was observed in this period. On the other hand, for the food waste slurry reactor, the concentration of suspended solids did not experience any sudden increase after increasing OLR to $3 \mathrm{gVS} / \mathrm{L} / \mathrm{day}$, however the solids accumulation rate was raised to $0.29 \mathrm{~g} / \mathrm{L} /$ day. The membrane performance was flawless and flux deterioration was negligible regardless of daily increases in suspended solids. The recovery of VFAs from the system consisted of a filtration cycle of about 1 to $3 \mathrm{~h}$ ( $210 \mathrm{~s}$ forward flow followed by $30 \mathrm{~s}$ backwash) and around $21 \mathrm{~h}$ relaxation. The average flux for the excess sewage sludge reactor was $5.53 \mathrm{~L} / \mathrm{m}^{2} / \mathrm{h}$ and it was stable during the most of fermentation time, although the obtained flux was significantly lower than the other study in this group [27] operating at the similar level of suspended solids. Lower flux may result in lower productivity; however, during the whole 3 months of fermentation (including the preparation time), chemical cleaning service was necessary only once, which indicated that the mentioned strategies were effective for mitigating membrane fouling. Moreover, lower frequency of chemical cleaning lessens the process downtime, chemical waste, and provision, which is favorable for an industrial process. For the food waste slurry AD MBR, the average flux was $16.18 \mathrm{~L} / \mathrm{m}^{2} / \mathrm{h}$ and, similarly to the excess sewage sludge reactor, only a single membrane chemical cleaning was needed. 
a
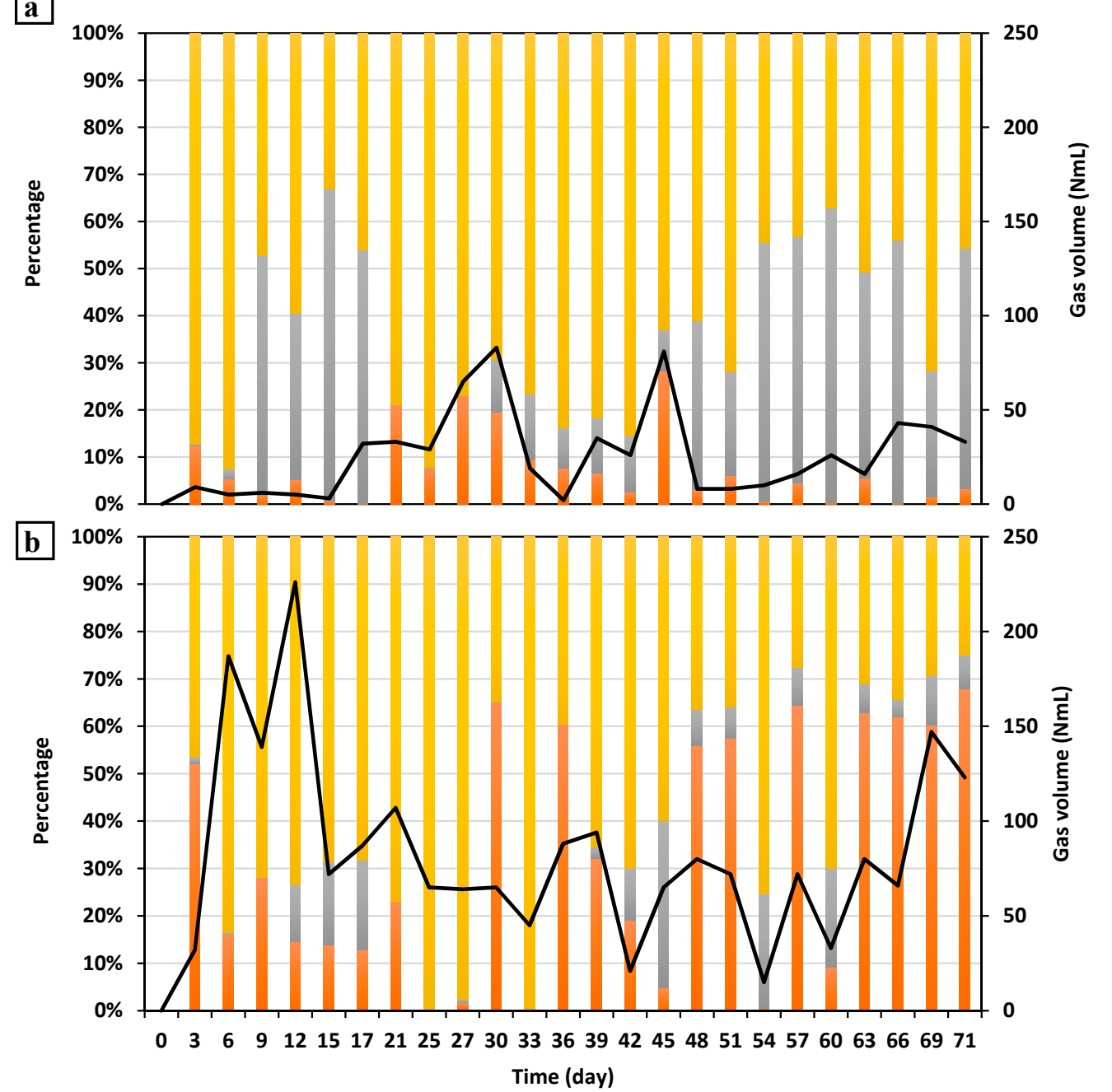

$\begin{array}{llll}\mathrm{H} 2 & \mathrm{CH} 4 & \mathrm{CO} 2-\text { Total gas }\end{array}$

Figure 11. Composition and volume of gas produced from (a) excess sewage sludge and (b) food waste slurry.

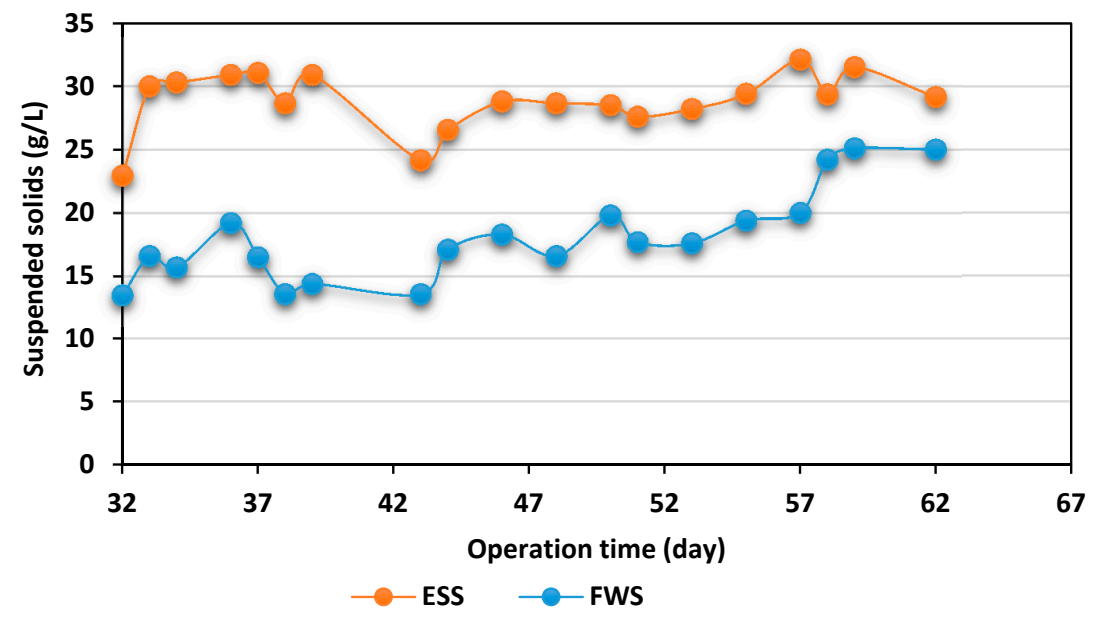

Figure 12. Suspended solid profiles of excess sewage sludge and food waste slurry iMBR. 


\subsection{Different Process Scenarios for the Production of VFAs for Application as a Denitrification Carbon Source}

In this section, the feasibility of the application of the developed iMBR set-up for the production of VFAs that can be further applied for denitrification purposes in WWT process is evaluated. As presented previously in other literature $[15,16,35]$, the VFA solution produced from the anaerobic digestion of different substrates such as sludge can positively contribute to the denitrification stage during a wastewater treatment process by providing the required carbon source. Using the carbon source produced sustainably from renewable residual sources, such as WWT excess sludge and other organic wastes (e.g., food waste) in the form of VFAs, provides the opportunity for a WWTP to employ circular economy measures. By integrating (or retrofitting) the iMBR set-up used in this research into the WWT process, the provision of VFAs from the above-mentioned sources is facilitated, which helps the realization of a WWT process independent of a fossil fuel source. In this regard, two hypothetic scenarios were considered for the application of excess sludge and food waste as the substrate for VFAs production using the iMBR (Figures 5 and 6). The base processing conditions in the assumed WWTP are presented in Table 3.

Table 3. The base processing conditions taken into account for the denitrification stage.

\begin{tabular}{cc}
\hline Parameter & Value \\
\hline In flow-denitrification $\left(\mathrm{m}^{3} / \mathrm{s}\right)$ & 2.5 \\
Denitrification $(\mathrm{kgN} / \mathrm{h})$ & 91.2 \\
C/N ratio $(\mathrm{kg}$ COD methanol $/ \mathrm{kgN})$ & 4.8 \\
Methanol COD consumption $(\mathrm{kgCOD} / \mathrm{h})$ & 439.4 \\
Methanol consumption $(\mathrm{kg} / \mathrm{h})$ & 298.9 \\
Methanol cost $(€ / \mathrm{kg})$ & 0.467 \\
Methanol cost $(€ / \mathrm{kgN})$ & 1.094 \\
Cost of methanol used per hour $(€ / \mathrm{h})$ & 139.6 \\
COD equivalent of methanol $($ ton COD $/$ ton methanol) & 1.47 \\
NO ${ }_{3}$ out through the effluent $(\mathrm{mg} / \mathrm{L})$ & 1.3 \\
VFA solution flow to denitrification inflow ratio & 0.0054 \\
\hline Cost of equivalent VFA COD production per hour $(€ / \mathrm{h})$ & 11.88 \\
\hline
\end{tabular}

As seen in Figure 5, scenario one considers the provision of the VFAs required for denitrification from an iMBR fed only with food waste. Based on the acquired results using the lab-scale iMBR, a VFAs COD equivalent of $9 \mathrm{~g} / \mathrm{L}$ can be achieved. The process conditions and the overall performance of this scenario are summarized in Table 4. In this condition, the VFA solution obtained as permeate is fed as an external carbon source to the denitrification stage.

Table 4. Process conditions and the overall performance of scenario one and two.

\begin{tabular}{|c|c|c|}
\hline & Parameter & Value \\
\hline Scenario 1 & $\begin{array}{c}\text { Total MBR volume } \\
\text { VFA production } \\
\text { Membrane area } \\
\text { Flow rate of VFA solution required for denitrification } \\
\text { Estimated price of VFA produced } \\
\text { Estimated cost of VFA production }\end{array}$ & $\begin{array}{c}11,700 \mathrm{~m}^{3} \\
298 \mathrm{Kg} / \mathrm{h}(440 \mathrm{KgCOD} / \mathrm{h} \text { equivalent }) \\
6510 \mathrm{~m}^{2} \\
0.5 \% \text { of the total denitrification flow }\left(49 \mathrm{~m}^{3} / \mathrm{h}\right) \\
\sim 238 € / \mathrm{h} \\
\sim 12-14 € / \mathrm{h}\end{array}$ \\
\hline Scenario 2 & $\begin{array}{c}\text { MBR volume } \\
\text { VFA production } \\
\text { Membrane area } \\
\text { Flow rate of VFA solution required for denitrification } \\
\text { Estimated price of VFA produced } \\
\text { Estimated cost of VFA production }\end{array}$ & $\begin{array}{c}7520 \mathrm{~m}^{3} \text { (same biogas reactor or new reactor) } \\
319 \mathrm{Kg} / \mathrm{h}(440 \mathrm{KgCOD} / \mathrm{h} \text { equivalent) } \\
4185 \mathrm{~m}^{2} \\
0.3 \% \text { of the total denitrification flow }\left(29.5 \mathrm{~m}^{3} / \mathrm{h}\right) \\
\sim 255 € / \mathrm{h} \\
\sim 8-10 € / \mathrm{h}\end{array}$ \\
\hline
\end{tabular}

In the second scenario, the provision of the VFAs equivalent to required methanol from the anaerobic digestion of excess sludge in the iMBR was considered (Figure 6). The process parameters 
were assumed to be roughly those considered for lab-scale experiments. In this regard, a VFAs COD-equivalent level of $14 \mathrm{~g} / \mathrm{L}$ was obtained. As can be seen in Table 4 , for the provision of the same amount of COD-equivalent VFAs for complete replacement of methanol with permeate from tested food waste iMBR, an iMBR with 1.6-times greater volume and membrane area compared to the sludge iMBR is required. This imposes a great additional capital cost on the WWTP if iMBR retrofitting/integration is to be aimed at. As estimated, using a sludge iMBR compared to a food waste fed iMBR reduces the operational cost of VFA production by $30-35 \%$. However, it should be considered that the presented scenarios suffer from the fact that the VFA solutions themselves carry an ammonium content that should be removed or converted prior to the addition of the VFA solution to the denitrification stage.

Another future scenario can include an iMBR set-up that benefits from both sludge and food waste as co-substrates. According to our previous studies [9,27], such a scenario would most likely yield higher VFAs and improve the $\mathrm{C} / \mathrm{N}$ ratios of the recovered VFAs solution (Figure 13).

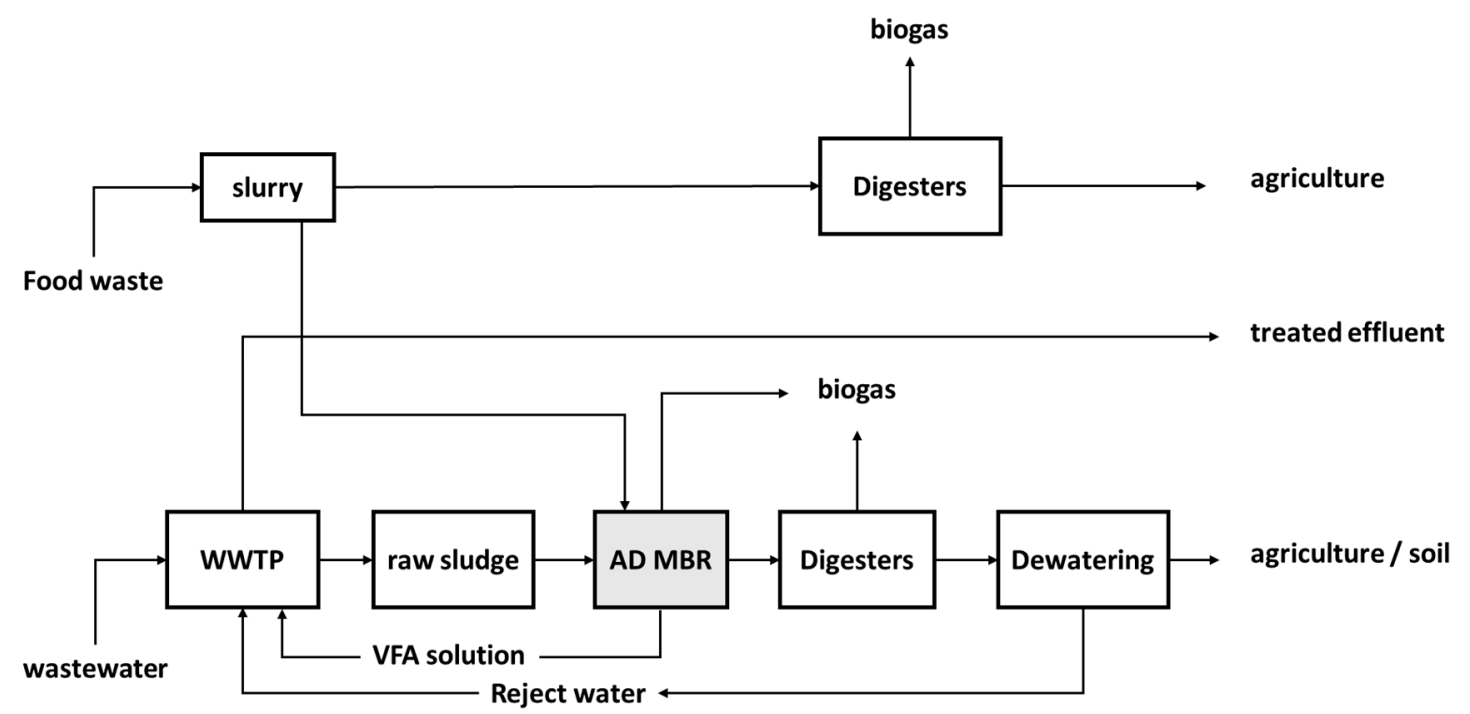

Figure 13. An overview of the proposed scenario with an MBR system treating sludge and food waste at Gryaab AB.

However, regardless of which scenario to apply, without the application of the iMBR the plant has to provide about $300 \mathrm{~kg}$ fossil-based methanol per hour with an estimated cost of about $140 € / \mathrm{h}$ (based on estimated prices in 2018). It should be noted that the ability of this specific VFA solution to replace methanol for denitrification has not been verified by denitrification tests and the theoretical calculations are based on COD. Using the established flexible iMBR technology, surplus VFA solution can be easily produced by changing the process parameters. Considering the VFAs solution's average market value of $0.6-0.8 € / \mathrm{kg}$, the WWTP or organic waste treatment facility can benefit from the obtained surplus VFAs. Using the proposed solution, the WWTP becomes more sustainable by circumventing the application of fossil-based methanol, recovers the nutrient content of the waste sludge and food waste to a high extent, and produces several value-added products, such as VFA and biogas, that can provide the basis for a WWTP biorefinery. However, to fully validate the proposed concept, further detailed study on the capital expenditures for integration or retrofitting the iMBR system into existing WWTPs (a biogas digester can be an option for conversion to iMBRs) should be conducted considering membrane filtration and process limitations, and the effect of ammonium nitrogen content of VFA solution on the final effluent quality. 


\section{Conclusions}

In this study, it was observed that a flat sheet iMBR set-up could successfully be used for stable production and in situ recovery of high concentrations of VFAs from excess sludge and food waste slurry in the long-term ( 3 months) semi-continuous process. To boost the digestibility of ESS and FWS, the effects of different mild thermal and thermochemical pretreatment conditions were investigated prior to iMBR fermentation. For both ESS and FWS, pretreatment with $\mathrm{NaOH}$ resulted in the highest increase in substrate SCOD and the roles of temperature and exposure time were minimal. The pretreatments did not affect the VFA concentration and $\mathrm{C} / \mathrm{N}$ ratio considerably in the case of using ESS as substrate, however, thermochemically pretreated FWS yielded higher VFAs concentrations compared to non-pretreated FWS. VFAs yields of $0.38 \mathrm{gVFA} / \mathrm{g} \mathrm{VS}$ added and $0.34 \mathrm{gVFA} / \mathrm{g} \mathrm{VS}_{\text {added }}$ were obtained, respectively, from ESS and FWS by applying anaerobic iMBR. The average flux for the excess sewage sludge reactor was $5.53 \mathrm{~L} / \mathrm{m}^{2} / \mathrm{h}$ while it was $16.18 \mathrm{~L} / \mathrm{m}^{2} / \mathrm{h}$ for the food waste slurry reactor. Considering different scenarios for the integration of the iMBR into the wastewater treatment process, it is estimated that using the proposed iMBRs working on food waste and/or sludge in a typical wastewater treatment plant can be a promising alternative to the provision of an external carbon source.

Author Contributions: Conceptualization, M.J.T., D.I., A.M. and S.W.; methodology, A.M., S.W. and M.P.; formal analysis, M.P., S.W. and A.M.; investigation, M.P. and S.W.; data curation, M.P.; writing original draft preparation, M.P., S.W., A.M.; writing review and editing, M.P., S.W., A.M., M.J.T. and D.I.; supervision, M.J.T. and D.I.; funding acquisition, M.J.T., A.M. All authors have read and agree to the published version of the manuscript.

Funding: This research was funded by Sweden's Innovation Agency, Vinnova (Sweden), grant number 2018-03732 and the Swedish Agency for Economic and Regional Growth through a European Regional Development Fund grant number 20201656, Gryaab AB (Sweden) and Renova AB (Sweden).

Acknowledgments: The authors would like to express their sincere gratitude to Ann Mattsson (Gryaab AB, Gothenburg, Sweden), Lia Detterfelt (Renova AB, Gothenburg, Sweden) and Claes Niklasson (Chalmers University of Technology, Gothenburg, Sweden) for their constant scientific and technical support of the project.

Conflicts of Interest: The authors declare no conflict of interest.

\section{References}

1. Viessman, W. Water Supply and Pollution Control; Pearson Education: London, UK, 2014.

2. Henze, M.; van Loosdrecht, M.C.M.; Ekama, G.A.; Brdjanovic, D. Biological Wastewater Treatment; IWA Publishing: London, UK, 2008.

3. Spellman, F.R. Handbook of Water and Wastewater Treatment Plant Operations; CRC Press: Boca Raton, FL, USA, 2013.

4. Eurostat. Sewage Sludge Production and Disposal from Urban Wastewater (in Dry Substance (d.s)). Available online: https://ec.europa.eu/eurostat/databrowser/product/view/TEN00030?lang=en (accessed on 27 February 2020).

5. Braguglia, C.M.; Gallipoli, A.; Gianico, A.; Pagliaccia, P. Anaerobic bioconversion of food waste into energy: A critical review. Bioresour. Technol. 2018, 248, 37-56. [CrossRef] [PubMed]

6. Paritosh, K.; Kushwaha, S.K.; Yadav, M.; Pareek, N.; Chawade, A.; Vivekanand, V. Food Waste to Energy: An Overview of Sustainable Approaches for Food Waste Management and Nutrient Recycling. Biomed. Res. Int. 2017, 2017. [CrossRef] [PubMed]

7. Kabir, M.M.; Forgács, G.; Taherzadeh, M.J.; Sárvári Horváth, I. Biogas from wastes: Processes and applications. In Resource Recovery to Approach Zero Municipal Waste; Richards, T., Taherzadeh, M.J., Eds.; CRC Press: Boca Raton, FL, USA, 2015; pp. 107-140.

8. Wainaina, S.; Lukitawesa; Kumar Awasthi, M.; Taherzadeh, M.J. Bioengineering of anaerobic digestion for volatile fatty acids, hydrogen or methane production: A critical review. Bioengineered 2019, 10, 437-458. [CrossRef] [PubMed]

9. Wainaina, S.; Parchami, M.; Mahboubi, A.; Horváth, I.S.; Taherzadeh, M.J. Food waste-derived volatile fatty acids platform using an immersed membrane bioreactor. Bioresour. Technol. 2019, 274, 329-334. [CrossRef] [PubMed] 
10. Kim, N.J.; Lim, S.J.; Chang, H.N. Volatile fatty acid platform: Concept and application. Emerg. Areas Bioeng. 2018, 1, 173-190.

11. Golterman, H. Denitrification in the Nitrogen Cycle; Springer: Berlin/Heidelberg, Germany, 2013; Volume 9.

12. Christensson, M.; Lie, E.; Welander, T. A comparison between ethanol and methanol as carbon sources for denitrification. Water Sci. Technol. 1994, 30, 83. [CrossRef]

13. Elefsiniotis, P.; Li, D. The effect of temperature and carbon source on denitrification using volatile fatty acids. Biochem. Eng. J. 2006, 28, 148-155. [CrossRef]

14. Fass, S.; Ganaye, V.; Urbain, V.; Manem, J.; Block, J.C. Volatile fatty acids as organic carbon sources in denitrification. Environ. Technol. 1994, 15, 459-467. [CrossRef]

15. Kim, H.; Kim, J.; Shin, S.G.; Hwang, S.; Lee, C. Continuous fermentation of food waste leachate for the production of volatile fatty acids and potential as a denitrification carbon source. Bioresour. Technol. 2016, 207, 440-445. [CrossRef]

16. Elefsiniotis, P.; Wareham, D.G.; Smith, M.O. Use of volatile fatty acids from an acid-phase digester for denitrification. J. Biotechnol. 2004, 114, 289-297. [CrossRef]

17. Elefsiniotis, P.; Wareham, D.G. Utilization patterns of volatile fatty acids in the denitrification reaction. Enzym. Microb. Technol. 2007, 41, 92-97. [CrossRef]

18. Longo, S.; Katsou, E.; Malamis, S.; Frison, N.; Renzi, D.; Fatone, F. Recovery of volatile fatty acids from fermentation of sewage sludge in municipal wastewater treatment plants. Bioresour. Technol. 2015, 175, 436-444. [CrossRef] [PubMed]

19. Lee, W.S.; Chua, A.S.M.; Yeoh, H.K.; Ngoh, G.C. A review of the production and applications of waste-derived volatile fatty acids. Chem. Eng. J. 2014, 235, 83-99. [CrossRef]

20. Trad, Z.; Akimbomi, J.; Vial, C.; Larroche, C.; Taherzadeh, M.J.; Fontaine, J.-P. Development of a submerged anaerobic membrane bioreactor for concurrent extraction of volatile fatty acids and biohydrogen production. Bioresour. Technol. 2015, 196, 290-300. [CrossRef] [PubMed]

21. Zacharof, M.P.; Lovitt, R.W. Recovery of volatile fatty acids (VFA) from complex waste effluents using membranes. Water Sci. Technol. 2014, 69, 495-503. [CrossRef]

22. Mumtaz, T.; Abd-Aziz, S.; Rahman, N.A.; Yee, P.L.; Shirai, Y.; Hassan, M. Pilot-scale recovery of low molecular weight organic acids from anaerobically treated palm oil mill effluent (POME) with energy integrated system. Afr. J. Biotechnol. 2008, 7, 3900-3905.

23. Mostafa, N.A. Production and recovery of volatile fatty acids from fermentation broth. Energy Convers. Manag. 1999, 40, 1543-1553. [CrossRef]

24. Chen, H.; Meng, H.; Nie, Z.; Zhang, M. Polyhydroxyalkanoate production from fermented volatile fatty acids: Effect of $\mathrm{pH}$ and feeding regimes. Bioresour. Technol. 2013, 128, 533-538. [CrossRef]

25. Huang, C.; Xu, T.; Zhang, Y.; Xue, Y.; Chen, G. Application of electrodialysis to the production of organic acids: State-of-the-art and recent developments. J. Membr. Sci. 2007, 288, 1-12. [CrossRef]

26. Mahboubi, A.; Ylitervo, P.; Doyen, W.; De Wever, H.; Taherzadeh, M.J. Reverse membrane bioreactor: Introduction to a new technology for biofuel production. Biotechnol. Adv. 2016, 34, 954-975. [CrossRef]

27. Wainaina, S.; Awasthi, M.K.; Horváth, I.S.; Taherzadeh, M.J. Anaerobic digestion of food waste to volatile fatty acids and hydrogen at high organic loading rates in immersed membrane bioreactors. Renew. Energy 2020, 152, 1140-1148. [CrossRef]

28. American Public Health Association; American Water Works Association; Water Pollution Control Federation; Water Environment Federation. Standard Methods for the Examination of Water and Wastewater; American Public Health Association: Washington, DC, USA, 1920.

29. Xue, Y.; Liu, H.; Chen, S.; Dichtl, N.; Dai, X.; Li, N. Effects of thermal hydrolysis on organic matter solubilization and anaerobic digestion of high solid sludge. Chem. Eng. J. 2015, 264, 174-180. [CrossRef]

30. Penaud, V.; Delgenes, J.P.; Moletta, R. Thermo-chemical pretreatment of a microbial biomass: Influence of sodium hydroxide addition on solubilization and anaerobic biodegradability. Enzym. Microb. Technol. 1999, 25, 258-263. [CrossRef]

31. Kim, J.; Park, C.; Kim, T.-H.; Lee, M.; Kim, S.; Kim, S.-W.; Lee, J. Effects of various pretreatments for enhanced anaerobic digestion with waste activated sludge. J. Biosci. Bioeng. 2003, 95, 271-275. [CrossRef]

32. Liu, C.-F.; Yuan, X.-Z.; Zeng, G.-M.; Li, W.-W.; Li, J. Prediction of methane yield at optimum pH for anaerobic digestion of organic fraction of municipal solid waste. Bioresour. Technol. 2008, 99, 882-888. [CrossRef] 
33. Zhai, N.; Zhang, T.; Yin, D.; Yang, G.; Wang, X.; Ren, G.; Feng, Y. Effect of initial pH on anaerobic co-digestion of kitchen waste and cow manure. Waste Manag. 2015, 38, 126-131. [CrossRef]

34. Hussain, A.; Filiatrault, M.; Guiot, S.R. Acidogenic digestion of food waste in a thermophilic leach bed reactor: Effect of $\mathrm{pH}$ and leachate recirculation rate on hydrolysis and volatile fatty acid production. Bioresour. Technol. 2017, 245, 1-9. [CrossRef]

35. Min, K.S.; Park, K.S.; Jung, Y.J.; Khan, A.R.; Kim, Y.J. Acidogenic Fermentation: Utilization of Wasted Sludge as a Carbon Source in the Denitrification Process. Environ. Technol. 2002, 23, 293-302. [CrossRef]

(C) 2020 by the authors. Licensee MDPI, Basel, Switzerland. This article is an open access article distributed under the terms and conditions of the Creative Commons Attribution (CC BY) license (http://creativecommons.org/licenses/by/4.0/). 